\title{
CASE STUDIES OF THE DESIGN, CONSTRUCTION AND CERTIFICATION OF ENERGY-EFFICIENT HOUSES IN THE REPUBLIC OF KOREA
}

\author{
Jungmann Choi \\ Soongsil University. 577 Olympic-ro, Songpa-gu, Seoul, Korea
}

jungmann.choi@gmail.com

\begin{abstract}
Passive houses with three principles of comfort, low energy and economic efficiency started from Germany in 2009. Passive houses must have a heating energy demand of less than $15 \mathrm{kWh} /\left(\mathrm{m}^{2} \mathrm{a}\right)$ per year, and there are currently about 4,000 passive houses certified in Europe. Currently, Korea has begun experimental construction of passive houses from 2005, and it started to introduce it in construction market from 2009. To date, 160 units have been certified, which differs from Europe in that Korea is certified as a passive house up to $50 \mathrm{kWh} /\left(\mathrm{m}^{2} \mathrm{a}\right)$. In order to establish this standard, Passive House Institute Korea (PHIKO) collected and analyzed the data of the completed buildings over the years.

As a result, Korea Passive House standard was newly defined considering the climatic condition (humidity and solar radiation) of Korea and the lifestyle of floor-heating and sitting on that. Of course, these standards are not definitive, and they are still underway, and if more data is accumulated, the standards can change.
\end{abstract}

\section{Keywords}

Passive house, climate of Korea, standard, life style.

\section{Passive House Certification Criteria}

Passive house definition in Europe is "a building with a heating energy demand of $15 \mathrm{kWh}$ or less per year." Of course, there are additional requirements such as primary energy requirements and air tighness standards (Feist, 1993). And the five principles for this goal are well known (https://passipedia.org/basics).

The passive house is designed to raise the air coming in through the ventilation system a little bit or get off to get a comfortable temperature, so of course, $15 \mathrm{kWh}$ is calculated based on air heating. This value is then calculated using PHPP based on the local climate data.

\section{Status of Passive House in Korea}

Experimental passive houses have been constructed in Korea since 2005, and about 175 passive houses have been certified to date. Housing is the most common, and offices and schools are also being built. In addition, many products that are essential for passive houses such as thermal bridge blockers have been developed, and passive houses in Korea are helping to make them more economical (https://passipedia.org/basics/building_physics_-_basics/heating_load). As a result, construction costs, which have risen by nearly $20 \%$ compared to exist-

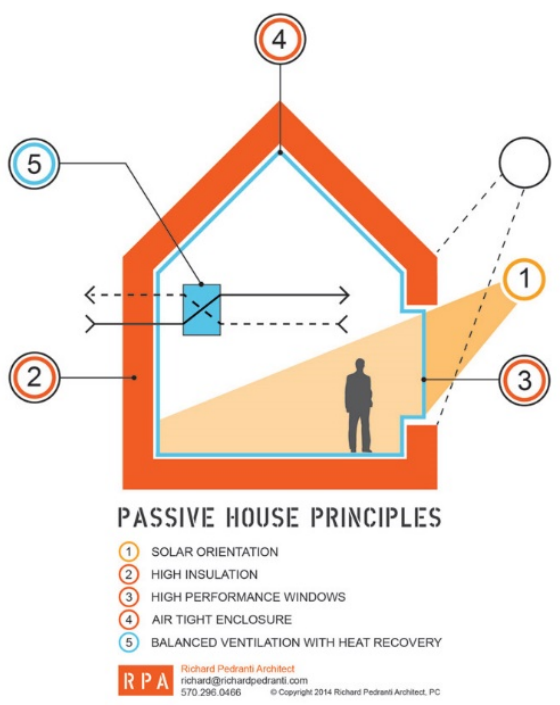

Figure 1. The five principles of Passive House (https://richardpedranti.com/passivehouse/)

ing buildings, are now stabilizing at around 10 15\%. Window's frame has been dependent on German products so far, but this part is expected to be available as Korean products. If it does, the cost of construction will be lower. 
Passive house technician training is held four times a year, and about 20 students graduate each time. About 300 people have been educated to date, and about $40 \%$ of graduates are architects (Bradshaw, 2006).

Recently, several passive Single-family housing complex are in the process of being designed and will start construction in 2018. One complex consists of 30 to 60 households, and five housing projects will be built nationwide (Bansal et al., 1994). These projects are meaningful because if the passive house was a market for a small construction company, it would be a chance that a middle-sized construction company will become interested in a passive house through this project.

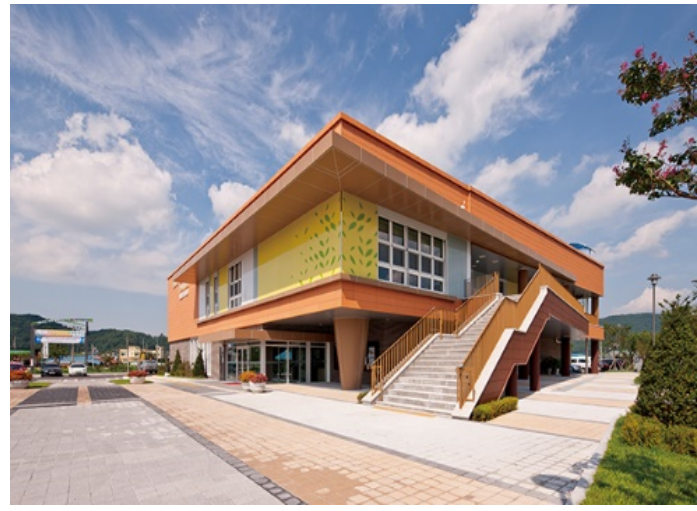

Figure 2. Community centre at Asan City

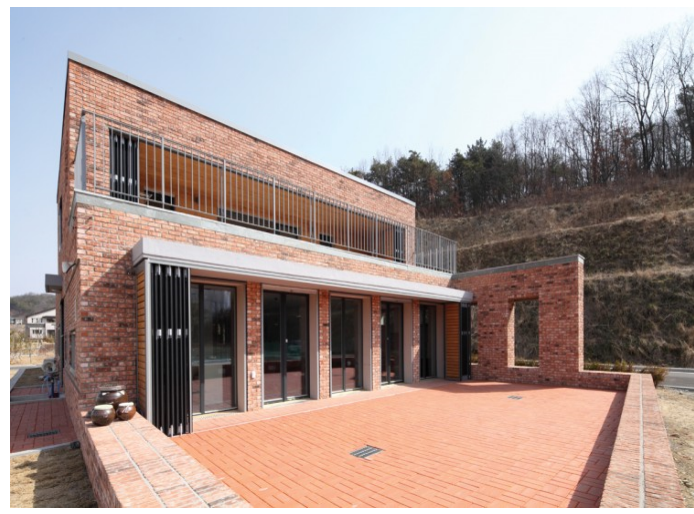

Figure 3. Lamda house, Desing by Doyoung Hong

\section{Characteristics of Passive House in Korea}

PHIKO has been monitoring the energy use and indoor environment of passive houses built in Korea over the years. And based on these results, we found that passive houses in Korea differ from those in Europe (Pèrez-Lombard et al., 2008).

This is a correlation between the exterior wall performance and the energy demand of the house. In Europe, the predicted value of energy performance is in agreement with the actual usage. In Korea, however, the actual usage is more than the calculated value is. That is, actual energy usage did not fall to European level.

The cause was the difference in lifestyle. Indoor temperature of a passive house is very comfortable. However, the floor temperature of the passive house in Korea, which is used to heating the floor, was low for Koreans to feel comfortable. (Temperature of floor heating: about $30^{\circ} \mathrm{C}$ ) Even though the temperature of the air was good enough, most Koreans had to operate the boiler to adjust the floor temperature. In addition, the climatic conditions are different (Feist, 1993).

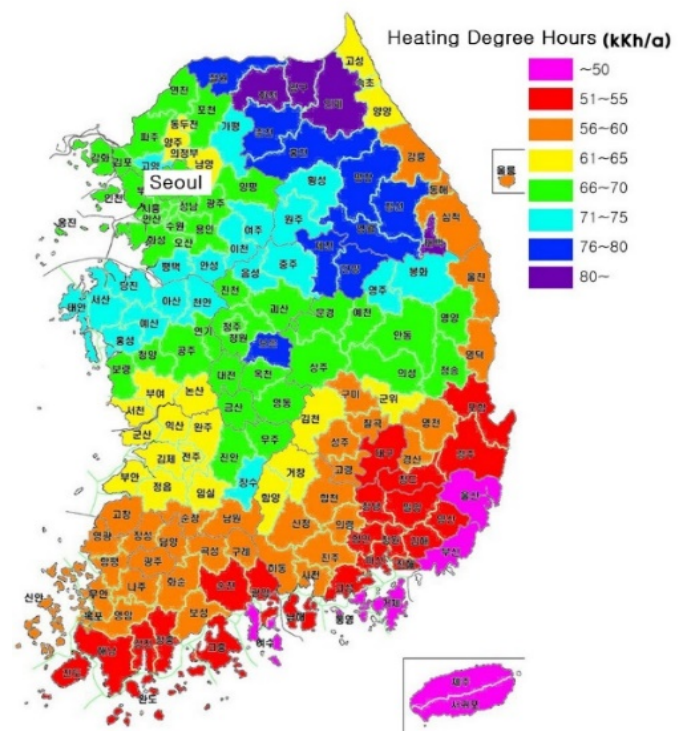

Figure 4. Heat Degree Hours in South Korea

In Korea, there is a tendency to be smaller than the heating degree hours mentioned in European passive house standards, but the difference in that between provinces is quite large. Also, summer is very humid in Korea. This high humidity will inevitably affect the design of the passive house. To understand this more precisely, we compared the average of passive houses built in Korea and European standard passive houses by several factors (Künzel and Holm, 2009). Based on these results, it is concluded that it is difficult to match the performance of the outer wall to the European level.

In addition to this, an important factor in Korea is that the humidity of summer is very high.

This part is very different from Europe, most of which is over $80 \%$ of summer humidity.

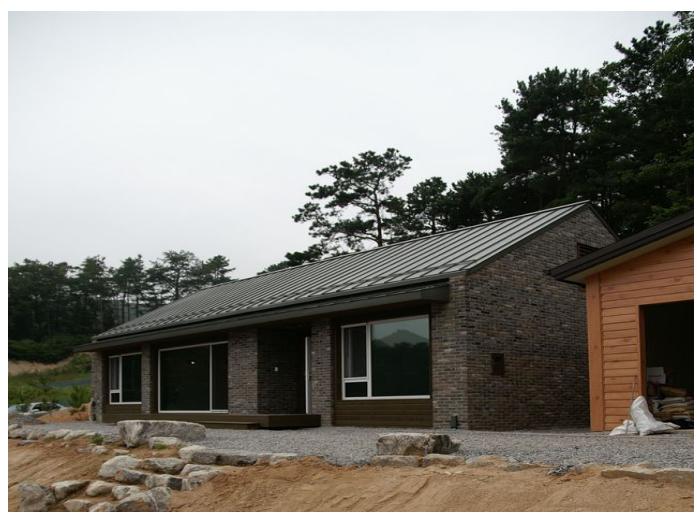

Figure 5. Standard Passive House by PHIKO 


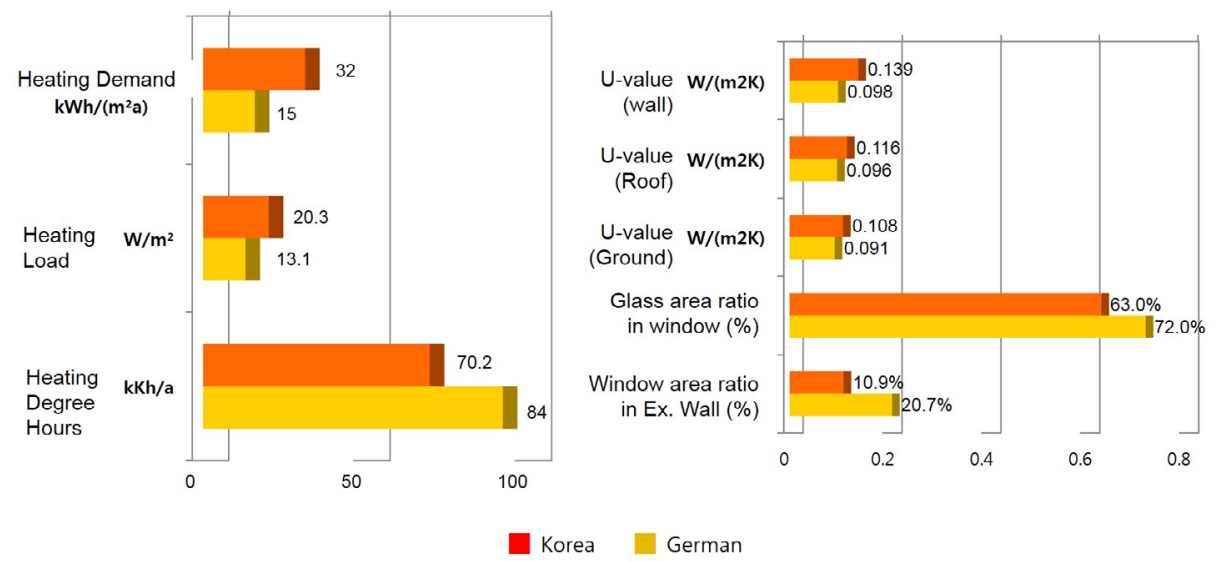

Figure 6. Performance comparison

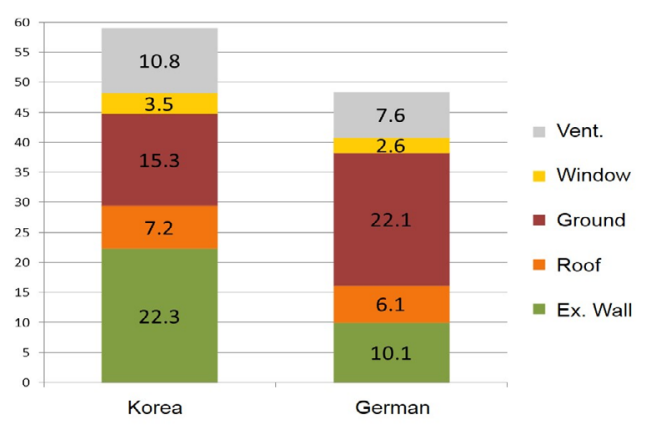

Losses

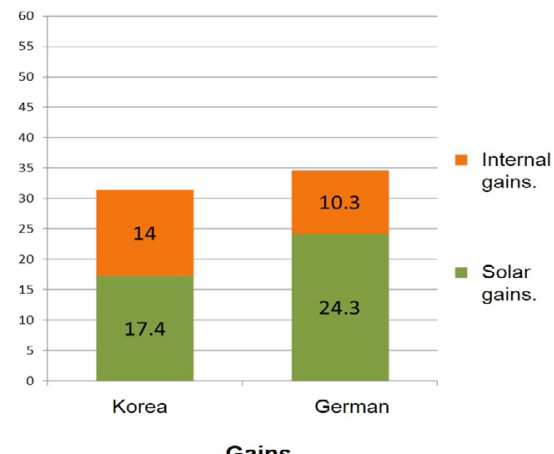

Gains

\begin{tabular}{cc}
\hline & Heating Demand $\mathrm{kWh} /\left(\mathrm{m}^{2} \mathrm{a}\right)$ \\
\hline Korea & 28.0 \\
German & 16.1 \\
\hline
\end{tabular}

Figure 7. Energy balance comparison
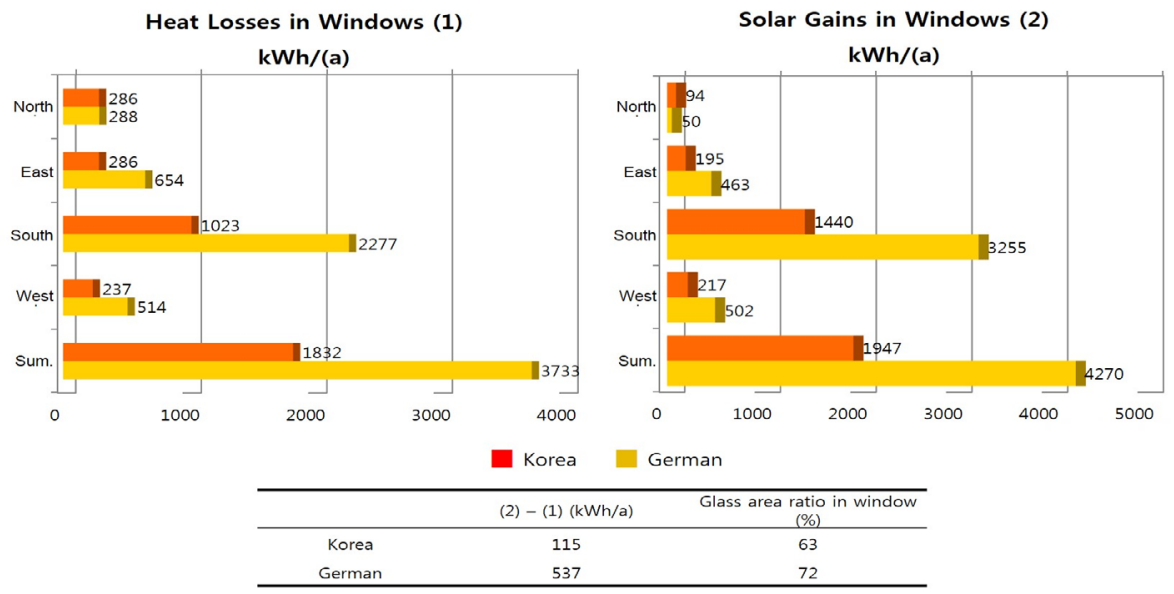

Figure 8. Solar Energy Gain cpmparison 

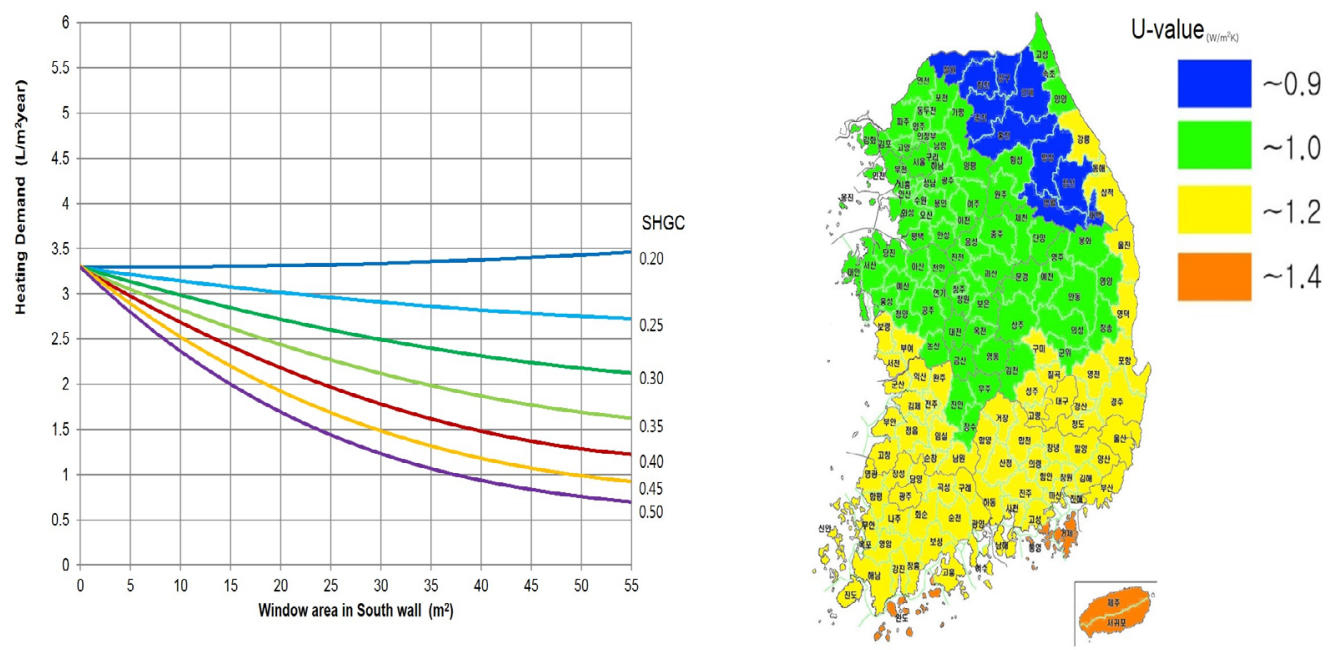

Figure 9. Windows performance standard of passive house in Korea

Field test site in Holzkirchen (alt.: $680 \mathrm{~m}$, lat.: $48^{\circ} \mathrm{N}$ )

Seoul (alt.: $20 \mathrm{~m}$, lat.: $37^{\circ} \mathrm{N}$ )
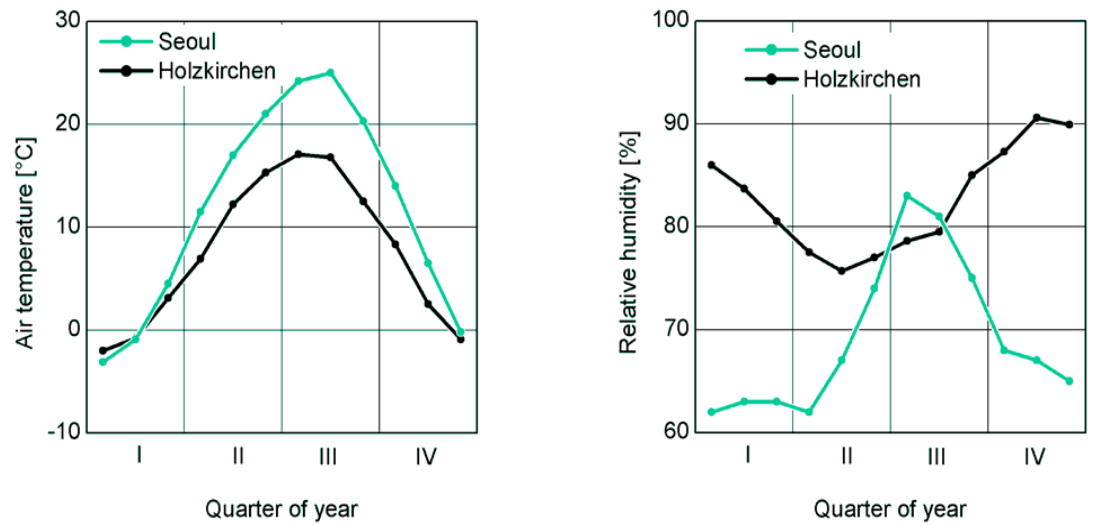

Figure 10. Differences in temperature and humidity between Germany and Korea by Fraunhofer

Table 1. Low Energy House and Passive House standard in Korea

\begin{tabular}{|c|c|c|c|}
\hline \multirow{4}{*}{} & & German $($ by PHI) & Korea (by PHIKO) \\
\cline { 2 - 4 } & Ex. Wall & $0.15 \mathrm{~W} / \mathrm{m}^{2} \cdot \mathrm{K}$ & $0.15 \sim 0.18 \mathrm{~W} / \mathrm{m}^{2} \cdot \mathrm{K}$ \\
\cline { 2 - 4 } & roof & $0.15 \mathrm{~W} / \mathrm{m}^{2} \cdot \mathrm{K}$ & $0.12 \sim 0.15 \mathrm{~W} / \mathrm{m}^{2} \cdot \mathrm{K}$ \\
\cline { 2 - 4 } & U-glass & $0.8 \mathrm{~W} / \mathrm{m}^{2} \cdot \mathrm{K}$ & $0.9 \sim 1.4 \mathrm{~W} / \mathrm{m}^{2} \cdot \mathrm{K}$ \\
\cline { 2 - 4 } & U-frame & $0.8 \mathrm{~W} / \mathrm{m}^{2} \cdot \mathrm{K}$ & $0.8 \sim 1.4 \mathrm{~W} / \mathrm{m}^{2} \cdot \mathrm{K}$ \\
\cline { 2 - 4 } & U-window & $0.85 \mathrm{~W} / \mathrm{m}^{2} \cdot \mathrm{K}$ & $0.9 \sim 1.5 \mathrm{~W} / \mathrm{m}^{2} \cdot \mathrm{K}$ \\
\cline { 2 - 4 } & glass g-value (SHGC) & 0.5 & 0.4 \\
\cline { 2 - 4 } & door & $0.8 \mathrm{~W} / \mathrm{m}^{2} \cdot \mathrm{K}$ & $1.2 \mathrm{~W} / \mathrm{m}^{2} \cdot \mathrm{K}$ \\
\hline \multirow{4}{*}{ Heat Exchanger } & Efficiency & $75 \%$ & $75 \%$ \\
\cline { 2 - 4 } & Power Consumption & $0.45 \mathrm{~W} / \mathrm{m}^{3} \cdot \mathrm{h}$ & $0.50 \mathrm{~W} / \mathrm{m}^{3} \cdot \mathrm{h}$ \\
\hline \multirow{4}{*}{ Performance } & Air tightness & $0.6 / \mathrm{h} \mathrm{@} \mathrm{50Pa}$ & $0.6 \sim 1.5 / \mathrm{h} @ 50 \mathrm{~Pa}$ \\
\cline { 2 - 4 } & Heating Demand & $15 \mathrm{kWh} / \mathrm{m}^{2} \cdot \mathrm{a}$ & $50 \mathrm{kWh} / \mathrm{m}^{2} \cdot \mathrm{a}$ \\
\cline { 2 - 4 } & Primary energy consumtion & $120 \mathrm{kWh} / \mathrm{m}^{2} \cdot \mathrm{a}$ & $150 \mathrm{kWh} / \mathrm{m}^{2} \cdot \mathrm{a}$ \\
\hline
\end{tabular}


So passive houses in Korea have more days of dehumidification load than cooling loads, and they are not considered in passive houses in Europe (Sadineni et al., 2011).

In particular, as the ventilation system was operated for 24 hours, the high humidity of the summer entered the room, causing the problem to be more serious. Passive houses in Korea will be an important goal to solve this summer moisture problem (Yongsang, 2014).

Passive house and Low energy house certification standard in Korea

Based on the data, PHIKO summarized the certification standards of passive houses certified in Korea as shown in the table 1 . This criterion is not yet finalized and may change as more measurements are accumulated (Sangtae, 2016). This data is still in progress, and in addition to these criteria, there will be added a mandatory requirement to address the above-mentioned summer humidity.

For this purpose, PHIKO has developed "Standard Passive House" for two years ago and has supplied about 16 houses with the same performance nationwide.

Since all houses with the same performance and design are located in different climates in Korea, the data from this house will have a great significance in determining Korea's passive house standards in the future. 


\section{Architecture and Engineering Volume 2 Issue 4}

\section{References}

Bansal, N.K., Hauser, G., Minke, G. (1994). Passive Building Design: a handbook of Natural Climatic Control. Amsterdam: Elsevier Science B.V.

Bradshaw, V. (2006). The Building Environment: Active and Passive Control Systems. New Jersey: Wiley.

Feist, W. (1993). Passive Houses in Central Europe. Dissertation. Kassel: Comprehensive University of Kassel.

Künzel, H.M., Holm, A.H. (2009). Moisture control and problem analysis ofheritage constructions. PATORREB: Encontro sobre Patologia e Rehabilitacaode Edifícios.

Parker, J., Hardy, A., Glew, D., Gorse, C. (2017). A methodology for creating building energy model occupancy schedules using personal location metadata. Energy and Buildings, 150, pp. 211-223. DOI: 10.1016/j.enbuild.2017.06.014

Pèrez-Lombard, L., Ortix, J., Pout, C. (2008). A review on buildings energy consumption information. Energy and Buildings, 40(3), pp. 394-398. DOI: 10.1016/j.enbuild.2007.03.007

Sadineni, S.B., Madala, S., Boehm, R.F. (2011). Passive Building energy savings: are view of building envelope components. Renewable and Sustainable Energy Reviews, 15, pp. 3617-3631. DOI: 10.1016/j.rser.2011.07.014

Sangtae, R. (2016). A Comparison of Insulation Performance between Domestic and International Passive House. Architectural Institute of Korea.

Wanga, Z., Wanga, Y., Srinivasan, R.S. (2017). A novel ensemble learning approach to support building energy use prediction. Energy and Buildings, 159, pp. 109-122. DOI: 10.1016/j.enbuild.2017.10.085

Yongsang, Y. (2014). A Study on the Correlation of Domestic Local Climate and Annual Heating Energy Demand - Focused on passive house performance buildings. Architectural Institute of Korea. 